\title{
The Application of Environmental Responsibility in Restaurant MSMEs in Bekasi Regency
}

\author{
Yunita Ismail ${ }^{1}$, Ahmad Solihin ${ }^{2}$ \\ 1) Faculty of Engineering, Environmental Engineering Department, President University \\ Jl. Ki Hajar Dewantara, Kota Jababeka,Cikarang, Bekasi - Indonesia 17550 \\ Email: yunitaismail@president.ac.id \\ 2) Faculty of Business, Management Department, President Univesity \\ Kota Jababeka,Cikarang, Bekasi - Indonesia 17550 \\ Email: ahmadsolihin6327@gmail.com
}

\begin{abstract}
In addition to the advancement of manufacturing industries, Bekasi Regency also has culinary as a supporting industry. It is undeniable that culinary is indeed one of the mainstays of business in Indonesia. Seeing the other side of the culinary business, it turns out that the culinary business has a fairly severe risk to the environment. FAO (Food and Agriculture Organization) states that leftover food waste contributes $10 \%$ of the world emissions of gas which causes greenhouse effects and other serious environmental impacts. The amount of risk caused by food waste is expected to be a concern and consideration for culinary businesses. So environmental damage is not getting bigger, and also can create a business that cares about the environment. To analyze the application of environmental awareness in restaurant MSMEs (Micro, Small, Medium Enterprises) in Bekasi Regency, this research using environmental responsibility variables as the dependent variable and independent variables, namely environmental awareness, environmental accounting reporting and environmental audits. This study uses quantitative research methods that take primary data from 150 restaurant SMEs actors in Bekasi District. Analysis of data with multiple linear regression methods shows that environmental attention and environmental audit variables have no significant effect on the implementation of environmental responsibility. In contrast, the environmental accounting reporting variable has a significant effect on the implementation of environmental responsibility in restaurant SMEs in the Bekasi District.
\end{abstract}

Keywords: environmental responsibility, environmental awareness, environmental accounting report, environmental audit, Restaurant MSMEs.

\begin{abstract}
ABSTRAK
Perkembangan usaha kuliner di Kabupaten Bekasi berkembang pesat dan dapat mendukung industri manufaktur yang banyak ditemukan di wilayah ini. Selain kemajuan industri manufaktur, Kabupaten Bekasi juga memiliki kuliner sebagai industri pendukung dan tidak bisa dipungkiri bahwa kuliner memang menjadi salah satu andalan bisnis di Indonesia. Melihat sisi lain dari bisnis kuliner, ternyata bisnis kuliner memiliki resiko yang cukup serius terhadap lingkungan. FAO (Food and Agriculture Organization) menyatakan bahwa sisa sisa makanan menyumbang 10\% dari emisi gas dunia yang menyebabkan efek rumah kaca dan dampak lingkungan serius lainnya. Besarnya risiko yang ditimbulkan oleh sampah makanan diharapkan menjadi perhatian dan pertimbangan bagi pelaku usaha kuliner. Dengan demikian, kerusakan lingkungan tidak semakin besar, dan juga dapat menciptakan usaha yang peduli terhadap lingkungan. Untuk menganalisis penerapan kesadaran lingkungan pada UMKM (Usaha Mikro, Kecil, Medium) restoran di Kabupaten Bekasi, penelitian ini menggunakan variabel tanggung jawab lingkungan sebagai variabel terikat dan variabel bebas yaitu kesadaran lingkungan, pelaporan akuntansi lingkungan dan audit lingkungan. Penelitian ini menggunakan metode penelitian kuantitatif yang mengambil data primer dari 150 pelaku UKM restoran di Kabupaten Bekasi. Analisis data dengan metode regresi linier berganda yang hasilnya menunjukkan bahwa variabel perhatian lingkungan dan audit lingkungan tidak berpengaruh signifikan terhadap pelaksanaan tanggung jawab lingkungan, sedangkan variabel pelaporan akuntansi lingkungan berpengaruh signifikan terhadap pelaksanaan tanggung jawab lingkungan pada UKM restoran di Bekasi Distrik.
\end{abstract}

Kata Kunci: tanggungjawab lingkungan, kesadaran lingkungan, pelaporan akuntansi lingkungan, audit lingkungan, UMKM restoran 


\section{Introduction}

Bekasi Regency is one of the most developed industrial areas in West Java (Budi, 2017). The advancement of industry in Bekasi Regency is directly proportional to the MSME sector (Micro, Small and Medium Enterprises); Bekasi Regency is recorded to have 225.844 MSME units, quite far above the West Java region average of 169.073 MSME units (BPS, 2017). According to the head of the MSME and Cooperatives Office of Bekasi Regency, the most dominant MSME business sector in Bekasi Regency is the culinary field. Still, no factual data records the exact number of culinary MSMEs in Bekasi Regency (Wardana, 2016). Culinary is one of the most popular businesses. Anggra (2018) revealed that one of the best-selling businesses in 2018 was the culinary business because the culinary industry is a staple of people's daily consumption and there are various types of creations. The diversity of cultures in Indonesia makes culinary colors in Indonesia very diverse. From Sabang to Merauke, each of which has its own unique culinary characteristics, it is not surprising that Indonesia is often used as a culinary tourism destination in the Southeast Asian region (Hanna, 2018).

Culinary contribution to the Indonesian economy is quite significant (Putra, 2018). Data published by BPS (Central Statistics Agency) and Bekraf (Creative Economy Agency) show that the contribution of Creative Economy (Creative Economy) to Indonesia's GDP (Gross Domestic Product) in 2016 was Rp.923 or $7.4 \%$ of the total national GDP, of this value, culinary has the largest role of IDR 328 trillion or $41 \%$ of the total creative economy sub-sector (Putra, 2018).

According to the United Nations Food and Agriculture Organization or FAO (Food and Agriculture Organization), food waste is food that is fit for consumption but is not consumed or disposed of by consumers. FAO in 2018 also stated that 1.3 million tons of edible food are wasted every year; this figure is equal to one-third of the production of edible food (Maharani, 2018). Not only that, 10\% of gas emissions that cause the greenhouse effect, also called FAO, come from food waste, which is the main factor that contributes to deforestation and the depletion of world water resources (Kumparan.com, 2018).

In Bekasi itself, on the other side of industrial progress, Bekasi also has a major problem: waste, the number of illegal landfills in several areas, and the amount of waste in river flows (Azzam, 2018). In addition, Bekasi Regency also has other problems; namely, it has not been able to manage the waste, it produces $100 \%$. There are still around 560 tons of waste per day that cannot be managed; the national waste composition data obtained from the Ministry of the Environment shows that food waste dominates the existing waste in Indonesia with 44\% (SIPSN, 2020).

From the discussion above, the environmental impact due to business activities, especially in the food sector, needs to be considered more seriously. Business activities should not only be oriented towards economic gain but must consider the environmental impacts that occur, as a form of responsibility to future generations. This research using environmental responsibility as a dependent variable, and independent variables are environmental awareness, environmental accounting report, and environmental audit.

Environmental responsibility is a mechanism by which a company voluntarily integrates business activities with social and environmental responsibilities beyond legal responsibilities (Hardianti 2017). Another theory regarding environmental responsibility is Choi and Mueller in Kurniawan (2015), stating that every company activity always involves social and environmental elements, starting from production, distribution, and operational activities. Therefore the company has a responsibility to the elements involved-support company activities. According to Kurniawan (2015), environmental responsibility is based on the triple bottom line principle, namely profit, people, and the planet. The triple bottom line principle means that every company is responsible for three things in running its business: economic, social justice, quality, and environment aspects. The company is obliged to convey social and environmental responsibility or CSR to interested parties. 


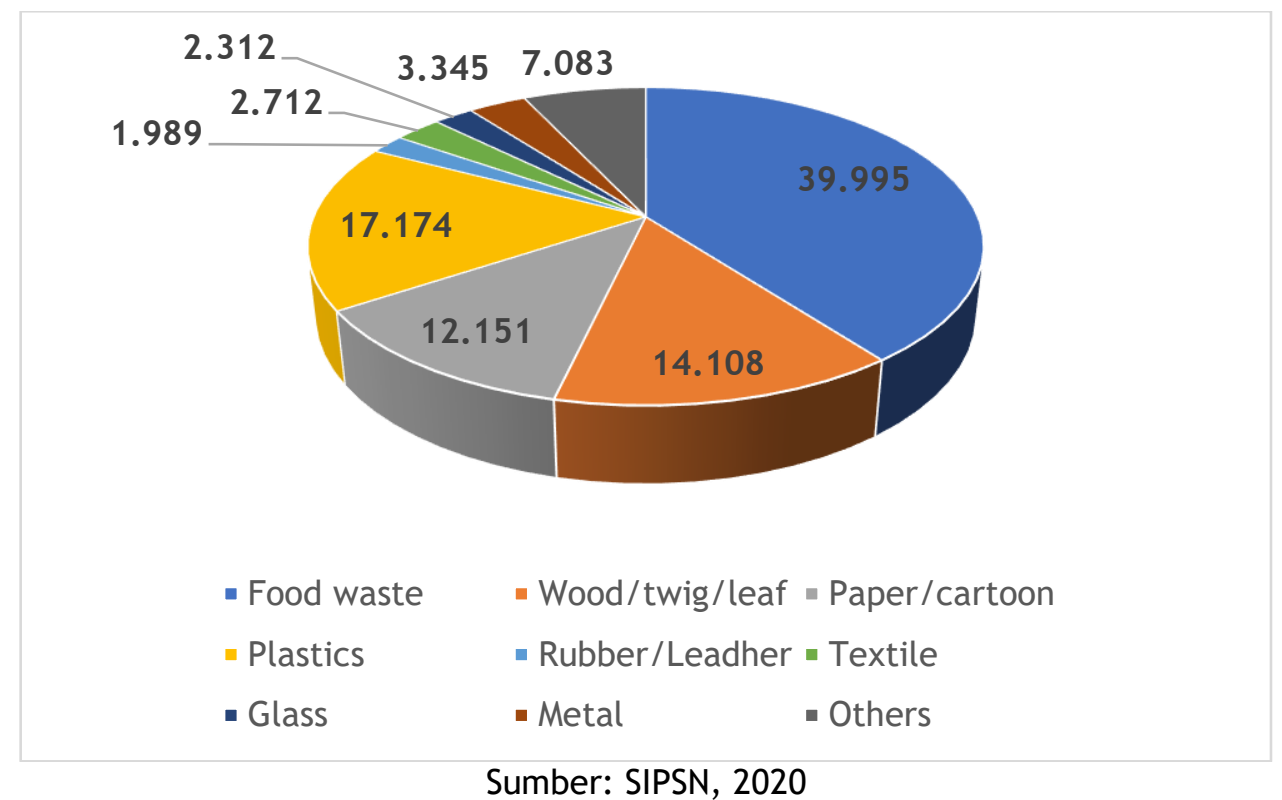

Figure. 1 Waste Composition in Indonesia

According to Li (2018), environmental awareness refers to the human process of absorbing, understanding, storing and organizing information from the environment. According to Musyarofah (2013), environmental awareness is influenced by several factors: ignorance, poverty, human, and lifestyle factors.

Variable environmental accounting report is a process of communicating social and environmental impacts caused by business activities to interested parties (Adam and Zutsi, 2004). The key indicator in environmental accounting report are explanation of environmental and social issues related to service or product operations and describe environmental performance indicators that are carried out to anticipate environmental impacts and explain about inputs and emissions, related to hazardous waste, waste that cannot be recycled, energy use and the impact of life cycle products.

Based on International Chamber of Commerce (ICC) 1991, definition of environmental audit is a management tool that contains a systematic evaluation, documented periodically and objectively, how well an organization is managing the environment and the equipment that is operated with the aim of protecting the environment, by:

a. Provide management control facilities on environmental practices.

b. Assess compliance with policies that have been made, as well as compliance with government regulations.

Then according to Ranggi (2010) states there are two understandings of environmental audit, namely:

a. Environmental audit is an environmental management system, environmental responsibility and environmental policy, practices, processes, procedures and managing environmental issues, as well as resources to protect the environment.

b. Environmental audit is an integral part of the environmental management system, as a tool used by management to assess whether the company's control system is capable enough to ensure compliance with internal policies and regulations, or in other words, environmental audit is for self-evaluation of whether the company is meeting internal policy objectives. and law.

The objectives of this research are:

1. To find out the influence of environmental awareness toward environmental responsibility of restaurant MSMEs partially at Bekasi Regency;

2. To find out the influence of environmental accounting report toward environmental responsibility of restaurant MSMEs partially at Bekasi Regency; 
3. To find out the influence of environmental audit toward environmental responsibility of restaurant MSMEs partially at Bekasi Regency;

4. To find out the influence of environmental awareness, environmental accounting report, and environmental audit toward environmental responsibility of restaurant MSMEs simultaneously at Bekasi Regency.

For the theoretical framework of this research showing in Figure 2.

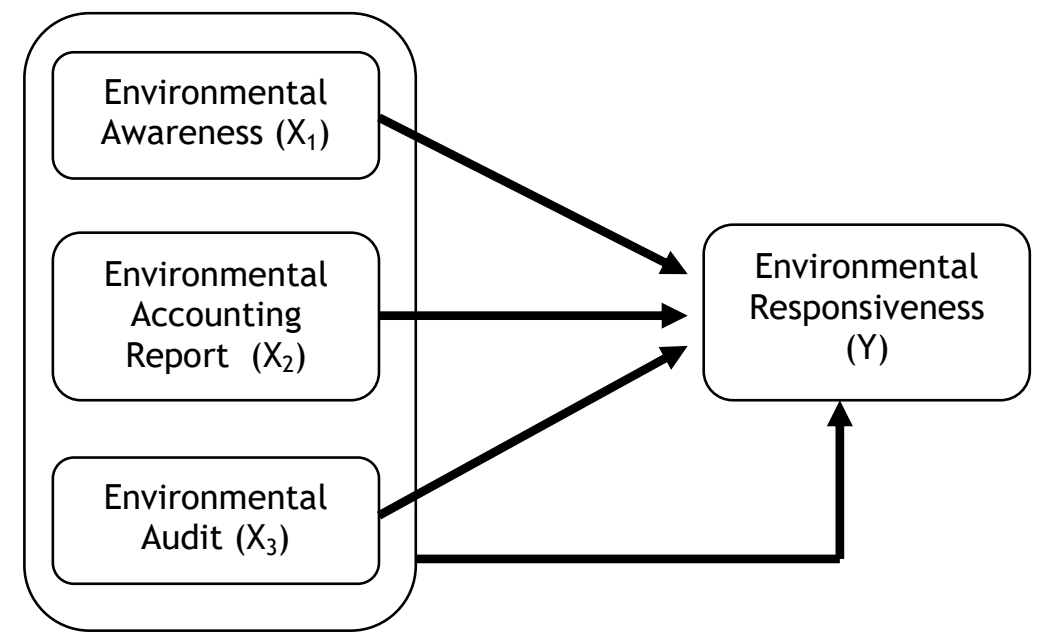

Figure 2. Theoretical Framework

From the Theoretical framework, the hypotheses proposed in this study are:

Hypothesis 1: There is a significant effect of environmental awareness on the implementation of environmental responsibility in restaurant SMEs in Bekasi Regency.

Hypothesis 2: There is a significant effect between environmental accounting report on the implementation of environmental responsibility in restaurant SMEs in Bekasi Regency.

Hypothesis 3: There is a significant effect of environmental audit on the implementation of environmental responsibility in restaurant SMEs in Bekasi Regency.

Hypothesis 4: There is a simultaneous effect between environmental awareness, environmental accounting report, and environmental audit on implementing environmental responsibility in restaurant SMEs in Bekasi Regency.

\section{Methods}

According to Law number 20 of 2008 concerning MSMEs, small businesses, in general, have started to carry out financial administration although it is still simple, and in terms of income and assets, according to Law number 20 of 2008, SMEs are classified as follows:

Table 1. SMEs Criteria

\begin{tabular}{|c|c|c|}
\hline \multirow[t]{2}{*}{ Business Size } & \multicolumn{2}{|c|}{ Criterias } \\
\hline & Asset & Omzet (year) \\
\hline Micro Business & $<50$ million IDR & $<300$ million IDR \\
\hline Smalls Business & 50 - 500 million IDR & $300-2,500$ million IDR \\
\hline Medium Business & $500-1000$ million IDR & $2,500-500,000$ million IDR \\
\hline
\end{tabular}

Roscoe (1975) in Hashim (2010) states that the number of samples between 30 to 500 is sufficient for almost all studies, and in this study, the researcher used a sample of 150 samples on the grounds that it was considered sufficient and also the limitations of the researcher. Then to determine the sample in this study using the convenience sampling method (Musyarofah, 2013), with criteria the SMEs locate in Cikarang and culinary business with asset less that 50 million IDR until 1000 million IDR. 
Primary data obtained directly by the researchers through questionnaires distributed to research respondents in accordance with the above criteria. In this study, there are two types of primary data that researchers get, namely the profile of the respondent and the results of the respondent's statement.

This study uses multiple linear regression data analysis method, multiple linear regression analysis aims to determine whether or not there is an influence of two or more variables $X$ or more on variable $\mathrm{Y}$. The relationship between the independent variable and the dependent variable is described in a mathematical model called multiple linear regression models such as the following formula:

$$
\begin{array}{ll}
\qquad Y=a+B_{1} X_{1}+B_{2} X_{2}+B_{3} X_{3}+e \\
Y & =\text { Dependent variable: Implementation of Environmental Responsibility } \\
\mathrm{e} & =\text { Residual } \\
B_{1}, B_{2}, B_{3} & =\text { Coefficient regression } \\
X_{1}, X_{2}, X_{3}= & \text { Independent variable: environmental awareness, environmental accounting } \\
& \text { report, environmental audit }
\end{array}
$$

\section{Result and Discussion}

\section{Descriptive Statistics}

In collecting data, questionnaire used as a measurement tools. This questionnaire pass validity and reliability test. The validity and reliability test for questionnaire done by used 30 respondent with coeeficient of correlation and cronbach alpha. All statements are valid and reliable.

From 150 respondents, the mean for the environmental awareness variable is 3.0467 and standard deviation of 0.6486 . The environmental accounting report's mean and standard deviation is 2.607 and 0.741 , respectively, 3.160 and 0.920 for mean and standard deviation for environmental audit. Mean, and standard deviation for all independent variables are closed to 3.00 with standard deviation of about 0,7 . It happens too for the dependent variable with a mean of 2.833, and

\begin{tabular}{|c|c|c|c|c|c|c|c|}
\hline \multirow[t]{2}{*}{ Model } & \multicolumn{2}{|c|}{$\begin{array}{l}\text { Unstandardized } \\
\text { Coefficients }\end{array}$} & \multirow{2}{*}{$\begin{array}{c}\text { Standardized } \\
\text { Coefficients }\end{array}$} & \multirow[t]{2}{*}{ t } & \multirow[t]{2}{*}{ Sig. } & \multicolumn{2}{|c|}{$\begin{array}{l}\text { Collinierity } \\
\text { Statistics }\end{array}$} \\
\hline & B & Std.Error & & & & Tolerance & VIF \\
\hline $\begin{array}{ll} & \text { (Constant) } \\
\end{array}$ & 4.725 & 1.562 & & 3.024 & 0.003 & & \\
\hline Environmental Awareness & 0.069 & 0.052 & 0.094 & 1.328 & 0.186 & 0.891 & 1.122 \\
\hline Environmental Accounting Report & 0.293 & 0.043 & 0.51 & 6.850 & 0.000 & 0.800 & 1.251 \\
\hline Environmental Audit & 0.128 & 0.095 & 0.099 & 1.350 & 0.179 & 0.823 & 1.216 \\
\hline
\end{tabular}
standard deviation is 0.746 .

Respondent answer foe all variables about neutral with smalls standard deviation.

\section{Multiple Regression Analysis}

Table 2 shows the result of multiple regression calculations.

Tabel 2. Multiple Regression Result

Dependent variable: environmental

responsibility

The multiple regression are: $Y=4,725+0,069 X_{1}+0,293 X_{2}+0,128 X_{3}$

From the model:

1. Constant is 4.725, it means if all independent variables (environmental awareness, environmental accounting report and environmental audit) are zero, the value of environmental responsibility variable is 4.725 ;

2. Coefficient of $X_{1}$ is 0.069 , it means if environmental awareness variable increase 1 unit, environmental responsibility variable will increase in 0.069 unit;

3. Coefficient of $X_{2}$ is 0.293 , it means if environmental accounting report variable increase 1 unit, environmental responsibility variable will increase in 0.293 unit; 
4. Coefficient of $X_{3}$ is 0.128 , it means if environmental audit variable increase 1 unit, environmental responsibility variable will increase in 0.128 unit;

The multiple regression model proceed to classical assumption test, which are normality, heteroscedasticity, and multicollinearity. Normality test using Kolmogorov Smirnov, and find the significance level is 0.164 , and it more than 0.05 . It means the error of the model is follow normally distribution. This model comply to heteroscedasticity and multicollinearity test too.

For significance test for the model (Table 2) showed that constant and environmental accounting report variable are significance, but environmental awareness and environmental audit are not significance.

To see the simultaneously influence used $f$ test. From Table 3 , showed that significance value is 0.000 . It means all independent variable simultaneously influence to environmental responsibility variable.

Tabel 3. F Test

\begin{tabular}{|ll|r|r|r|r|r|}
\hline Model & $\begin{array}{c}\text { Sum of } \\
\text { Squares }\end{array}$ & df & Mean Square & F & \multicolumn{2}{|c|}{ Sig } \\
\hline 1 & Regression & 623.002 & 3 & 207.667 & 26.473 & 0 \\
\hline Residual & 1145.291 & 146 & 7844 & & \\
\hline Total & 1768.293 & 149 & & & \\
\hline
\end{tabular}

\section{Conclusion}

From the results of the data analysis above, it can be concluded as follows:

1. Environmental awareness has an insignificant effect on the implementation of environmental responsibility in Restaurant SMEs in Bekasi Regency;

2. Environmental accounting reporting has a significant influence on the implementation of environmental responsibility in restaurant SMEs in Bekasi Regency;

3. Environmental audits have no significant effect on the implementation of environmental responsibility in restaurant SMEs in Bekasi Regency;

4. Environmental concerns, environmental accounting reporting, and environmental audits significantly affect the implementation of environmental responsibility in restaurant SMEs in Bekasi Regency, West Java.

Researcher suggestions regarding research results SME business actors, especially the food industry, should further increase their concern for the environment, starting with simple actions with consistency and for government agencies, support and regulation are needed to create economic growth and environmental sustainability.

For further research, in this study the variables are still very limited in their influence on the implementation of environmental responsibility, further research can focus on other variables that are considered to have a greater influence on the implementation of environmental responsibility.

\section{Acknowledgement}

Thanks are conveyed to Ahmad Solihin, a student of the Management study program, Faculty of Business, President University, who has been pleased to provide data on the measurement results. Thanks are also conveyed to the Head of Management Study Program President University who has been pleased to appoint the author as a thesis supervisor from Ahmad Solihin.

\section{References}

1. Adams, C., dan Zutshi, A. (2004). Corporate Social Responsibility: Why Business Should Act Responsibly And Be Accountable. Australian Accounting Review. Vol. 14 No. 3, 31-39.

2. Anggra R. (2018, September 26). Kuliner adalah salah satu usaha yang paling digemari. Retrieved from IDN Times: https://www.idntimes.com/business/economy/ayu-anggraeni/7peluang-bisnis-paling-laris-sepanjang-1 
3. Azzam, M. (2018, September 10). Sampah Jadi Masalah Utama, Ini Langkah Kadis Lingkungan Hidup Kabupaten Bekasi. Retrieved from Wartakotalive.com: wartakota.tribunnews.com/2018/09/10/sampah-jadi-masalah-utama-ini-langkah-kadislingkungan-hidup-kabupaten-bekasi

4. $\quad$ BPS (2017, Mei 24). Hasil Pendaftaran (Listing) Usaha/Perusahaan Sensus Ekonomi 2016 Provinsi Jawa Barat. Retrieved from Badan Pusat Statistik: https://se2016.bps.go.id/

5. Budi, K. (2017, September 18). Menatap Bekasi dan Proyeksi Ekonomi Mendatang. Retrieved from Kompas.com: https://sorot.kompas.com

6. Wardana. (2016, Januari 28). Bisnis Kuliner Pilihan Utama Pelaku UMKM Kabupaten Bekasi. Retrieved from Dakta.com: www.dakta.com

7. Hanna, Y. (2018, Februari 12). Yuk Kita Lihat Fakta 5 Fakta Seru Kuliner di Indonesia. Retrieved from Bobo.id: www.bobo.grid.id

8. Hardianti. (2017). Peran Green Accounting Dalam Upaya Mencegah Pencemaran Lingkungan Untuk Menunjang Keberlangsungan Usaha. Fakultas Ekonomi dan Bisnis Islam. UIN Alauddin Makassar.

9. Hashim, Y. (2010). Determining Sufficiency Of Sample Size In Management Survey Research Activities. International Journal Of Organisational Management And Entreprenuership Development. 6. 119-130.

10. Kurniawan, P. (2015). Konsep Tanggung Jawab Sosial Dan Lingkungan Perusahaan Dan Social And Environmental Accounting Sebagai Wujud Implementasi Enterprise Theory. Kumpulan Riset Akuntansi. Program Studi Akuntansi Universitas Warmadewa. 7. 66-77.

11. Li, Y. (2018). Study Of The Effect Of Environmental Education On Environmental Awareness And Environmental Attitude Based On Environmental Protection Law Of The People's Republic Of China. Eurasia Journal of Mathematics, Science and Technology Education, 14(6), pp.22772285.

12. Maharani, S. (2018, Juli 10). 1,3 Triliun Ton Makanan Terbuang Setiap Tahun, Bagaimana Mengatasinya? Retrieved from Kumparan: https://kumparan.com/@kumparanfood/1-3-triliunton-makanan-terbuang-setiap-tahun-bagaimana-mengatasinya-27431110790542298

13. Musyarofah, S. (2013). “Analisis Penerapan Green Accounting di Kota Semarang”. Skripsi. Jurusan Akuntansi. Fakultas Ekonomi. Universitas Negeri Semarang.

14. Putra, C. (2018, Februari 28). BEKRAF dan BPS Rilis Buku Statistik Ekonomi Kreatif.Retrieved from BEKRAF: www.bekraf.go.id/berita/page/10/bekraf-dan-bps-rilis-buku-statistik-ekonomikreatif

15. Ranggi. (2010). Analisi Pengaruh Audit Lingkungan Terhadap Realisasi Corporate Social Responsibility. Program Studi Ekonomi dan Bisnis. UIN Syarif Hidayatullah jakarta.

16. Susilo, J. (2008). Green Accounting Di Daerah Istimewa Yogyakarta: Studi Kasus Antara Kabupaten Sleman Dan Kabupaten Bantul. Program D3 Ekonomi Universitas Islam Indonesia

17. SIPN (2018, Februari 25). Data Umum Pengelolaan Sampah. Retrieved from SIPN (Sistem Informasi Pengelolaan Sampah Nasional): http://sipsn.menlhk.go.id/?q=3a-data-umum 